\title{
Using CAMEL To Predict Management Behavior In Indonesia's Sharia Bank
}

\author{
Yetty Murni ${ }^{1}$, Tri Astuti ${ }^{2}$, Chaerani Nisa ${ }^{3}$, Syahril Djaddang $^{4}$ \\ ${ }_{1,2,3,4}$ (Faculty of Economy and Business, Universitas Pancasila, Indonesia)
}

\begin{abstract}
All of the sharia Bank in Indonesia should met the CAMEL criteria that have been used by Central Bank in Indonesia. CAMEL itself stands for Capital, Asset, Management, Earning and Liquidity. The purpose of this research is to see whether CAMEL able to predict management behavior in sharia bank in Indonesia. The model itself is based on Grange Causality which is introduced by Berger \& DeYoung (1997) and then later used by Reddy (2011) to observe banking management behaviour in India. Based on the research, we found that sharia bank in Indonesia experienced a bad management hypothesis.
\end{abstract}

Keywords : CAMEL, Sharia Bank, management behavior, Granger Causality

\section{Introduction}

The banking industry have an important role in the economy of a country. Their role as an intermediary between the parties that excess money (surplus) with those who need money (deficit) makes banks play a vital role. As we already know, the real sectors need financing to make them grow faster and bigger. Economy is often determined by the ups and downs of growth in lending by banks. On the other hand, many times country status is determined by the level of savings in that country. The higher the savings ratio, meaning the higher the awareness of the public in preparing for life in the future and also indicates the excess revenue to be saved. Thus, reliable financial institutions also needed by public. Communities need to feel secure in placing their funds. However, without leaving the ability of banks to provide attractive yields as well as have a clear mission in its operations.

Another important role banks can also be seen from the crisis that hit the world economy in the last two decades. The crisis that occurred in the last 20 years largely due to the downfall of banking sector. Starting from the reduced public confidence in the bank, which resulted in a rush or a massive withdrawal of funds then have an impact on the banking sector as a whole. This is called systemic risk, which the government in this regard through the monetary authority, Bank Indonesia and the Financial Services Authority endeavor to prevent it (Achan, 2014).

One of the example is the economic crisis that hit Indonesia in 1998. Various studies have shown that if the only factor KKN (corruption, collusion, and nepotism) that caused the crisis is too simple. Even a few years earlier, before the crisis, it is precisely these factors which is said to represent the uniqueness of the countries in Asia that causes them different from other countries in the world. Through further research, it was discovered the causes of the crisis can be divided into two, namely the sources of fragility and the trigger of the crisis.

The review further found these two factors together occurred largely between August 1997 and March 1998. The biggest source of fragility, and is a fundamental weakness, is Indonesia's banking sector is overly rely on assurances from the government, but do not have enough capital and good regulation (Shalendra D. Sharma, 2001). (Enoch, Charles; Baldwin, Barbara; Frecaut, Olivier; Kovanen, 2001) concluded that approximately the same thing in his writings. A weak banking sector, compounded by the problems that occurred in the government, made the implementation of the solution becomes too late. Although various strategies has been tried to be formulated in the first months of the crisis, but lags in the implementation of solutions made the impacts have spread to the banking sector as a whole. At the end of 1999, critical points for the improvement of the banking sector have been implemented and the political transition that occurs already at the good stage. However, the government still can't just stay and must be prepared to face the challenges ahead.

While on the other hand, to support the intermediation function, Bank Indonesia has encouraged the growth of Islamic banking. Bankers welcomed this decision with joy. This is shown by the increasing of banks or financial institutions that operate shariah (Imansari, 2015). In addition, growth is also indicated by the increasing total Islamic banking assets over the last five years. Undeniably, the decision to use the services of Islamic banks because of the concepts used in accordance with the beliefs of most Indonesian people.

Islamic banks should ensure that the principles of Shariah Business Good Governance (GGBS) used as a reference in every aspect and operational activities of daily (Bank Muamalat, 2015). Spiritually, in order to obtain the blessing, Islamic finance should based on faith and piety embodied in the form of a commitment to two basic principles, namely lawful and Tayib (good) as Allah SWT says in surah Al-Baqarah / 2: 168. 
On the other hand, the high NPL is often cited as the cause of the collapse of a bank (Demirgüc-Kunt, 1989). More less the same conclusions derived from studies conducted by (Whalen, 1991). While other studies mentioned, the inefficiency of a bank lead to a high possibility of the bank experiencing financial difficulties or bankruptcy. (Berger, Hunter, \& Timme, 1993) specifically examine the conduct review related to the condition. (Reddy, 2011) combines the two conditions to view the behavior of the management of commercial banks in India. Research results show that commercial banks in India have no skimping behavior, but for banks with low capital have proven moral hazard. Based on this analysis, this study will examine the behavioral management of sharia banks in Indonesia by using CAMEL. The study will look at all banks that listed as sharia commercial bank in 2010 until 2014.

\section{Literature Review}

Berger and DeYoung (1997) is one the earlier researcher who is studied about the effect of loan quality and efficiency on banking performance. In this research, they stated four hypothesis. The first hypothesis is bad luck hypothesis. In this hypothesis, external factors precede the increase in troubled loans. The bad loans causing an increase in operating costs, banks have to monitor problem loans. Other than that, interest income also decreased caused by interest payments in arrears. Thus, based on this hypothesis, rising in NPLs led to increases in operating costs.

The second is bad management hypothesis. In this hypothesis, the low efficiency is the cause of the high NPLs. It is seen from the ability of management to manage the company. Bad management for example can be seen from the lack of management capabilities in monitoring a loan, does not have a network that is wide enough to get a prospective customer quality. In addition, manager does not have the ability to conduct a well assessment on the collateral. This condition is the underlying hypothesis that low value of the efficiency of a bank loan resulted in the bank experienced a high trouble loan.

The third one is skimping hypothesis. It emphasizes the tradeoff between efficiency in the short term but cause an increase in bad loans in the future. In the short term bank looks efficient, due to savings in the binding of loans and loan monitoring, but in the future these conditions can cause a rise in troubled loans. In skimping hypothesis, bank efficiency expected to have relationship with troubled loans with a positive relationship. While for the fourth hypothesis, the declining source of revenue led to the bank's capital worsened. When capital down further the bank more motivated to increase lending risk, so that the troubled bank term loan can be increased. Thus, the hypothesis of moral hazard is the decrease in bank's capital led to increased problem loans(Podpiera \& Weill, 2008).

In his research, Berger and DeYoung found the bad luck hypothesis happen in commercial bank in US from 1985 until 1994. Which is operating cost went high because bank have to dealt with non performed loans. However, the impact to economic is quite small. Meanwhile, in NPL equation, bad management happened mostly than the skimping hypothesis. In terms of moral hazard, this hypothesis had been found in bank with relatively low capital.

Rossi, Schwaiger and Winkler (2005) study bank efficiency in nine Central and Eastern European Countries and relationship with behaviour management. Those countries are in process on became European Union countries. This research important since many of those banks will be compete with foreign ownership bank. This research find that many of those banks have the ability in dealing with cost efficiency. While in terms of profit eficiency, they still lack of ability to control it. In management behaviour, there's no significant evidence that one of these hypothesis happen, eventhough there's negative correlation between problem loans and efficiency. The result for bad luck hypothesis shows that exogeneity of bad loans triggering inefficiency. Reddy (2011) investigate management behaviour in commercial banks in India. Reddy classified banks into three ownership groups which are public sector, private domestic and foreign banks. This study find bad management and bad luck hypothesis are happen in most banks in India. While for skimping hypothesis, there's no evidence this condition is happened in most cost efficient banks. On the contrary, banks with the least capital adequacy shows the characteristic of moral hazard. Quadt and Nguyen (2016) observe four hypothesis and one additional hypothesis, regulatory hypothesis, in Nordic banking sector. These five hypothesis are tested based on relationship between efficiency ratio, non performing loans, and capital. The result shows bad luck hypothesis appear in Nordic banks. Which suggests that external factors cause non performance loan to increase and after that a decrease in efficiency.

\section{Methods}

Granger Causality tests used by Berger and DeYoung (1997) was applied in this study to look at the behavior of management in Islamic banking in Indonesia.Behavior management analogy as intertemporal relationship between the problem loans, and capital efficiency. These three equation predicted to see four types of behavior management, namely, bad management, bad luck, skimming and moral hazard. Granger Causality framework are as follows (Reddy, 2011). 


$$
\begin{aligned}
& N \mathrm{PL}_{i, t}=f_{1}\left(\mathrm{PPL}_{i, \text { lag }}, N O M_{i, \text { lag }}, C A R_{i, \text { lag }}, \text { Quick Ratio } \text { Rlag }_{i}\right) \text { (1) } \\
& N O M_{i, t}=f_{1}\left(N \mathrm{PL}_{i, \text { lag }}, N O M_{i, \text { lag }}, C A R_{i, \text { lag }}, \text { Quick Ratio }_{i, \text { lag }}\right) \text { (2) } \\
& C A \mathrm{P}_{i, t}=f_{1}\left(\mathrm{NPL}_{i, \text { lag }}, \mathrm{NOM}_{i, \text { lag }}, \mathrm{CAR}_{i, \text { lag }}, \text { Quick Ratio }_{i, \text { lag }}\right) \text { (3) }
\end{aligned}
$$

Where:

NPL $=$ level of NPLs

$\mathrm{NOM}=$ Net Operation Margin

$\mathrm{CAR}=$ Capital adequacy ratio

Quick Ratio $=$ Comparison between current assets to short term liabilities

The population in this study is all Islamic financial institutions in Indonesia that operates at 2010 to 2014 . While the sample is determined by purposive sampling method, the sample is selected based on certain criteria.

\section{Result And Discussion}

The data used in this study are banks that include as sharia commercial banks. In 2016, 12 banks in the category of Islamic banks. The banks are:

1. PT. Bank Muamalat Indonesia (BMI)

2. PT. Bank Victoria Syariah (BVS)

3. PT. Bank BRI Syariah (BRIS)

4. PT. Bank Jabar Banten Syariah (BJBS)

5. PT. Bank BNI Syariah (BNIS)

6. PT. Bank Syariah Mandiri (BSM)

7. PT. Bank Mega Syariah (BMS)

8. PT. Bank Panin Syariah (BPS)

9. PT. Bank Syariah Bukopin (BSB)

10. PT. BCA Syariah (BCAS)

11. PT. Maybank Syariah Indonesia (MSI)

12. PT. National Savings Bank Syariah (BTPNS)

All ratios are collected from all of these banks. Descriptive statistic shows that that all sharia banks have follow the regulation that has been stated by Indonesia Financial Service Authority (FSA). FSA regulate that minimum CAR is $8 \%$. And based on the table, the lowest CAR is $10 \%$. While the average CAR is $24 \%$. It shows that most of the sharia banks in Indonesia are risk averse.

Meanwhile, all sharia banks have a fair level of NPF. While for Net Operation Margin, the value is quite different. It range from $0.8 \%$ to $33,3 \%$. Since many of these banks are just operated so it may still have low profit. While quick ratio is relatively moderate with average value is $53.35 \%$.Equation (1) until (3) are estimated using panel least square method. Basically these equations are based on Granger Causality Test. Before the model can be implemented, multicollienearity is tested to find out whether there's a collinearity between independent variable. Based on pairwise correlation test, there is no collinearity on those variable. Other tesst that applied are normality test, serial correlation test and heteroskedasticity. We found the possibility of homoskedasticity is happened and we managed to it by using weighted.

CAMEL used for testing the soundness of banks using data CAMEL. It modified to see the possibility of a four hypothesis of management behavior. (Reddy, 2011; Rossi et al., 2005) use three equations to test it. The equation basically adopted the Granger Causality test, where the dependent variable regressed by the lagged dependent variable itself. The other independent variables are lagged from the exogenous variables The result shows that bad management hypothesis is happen in shariah bank in Indonesia. It shows that the lower of the efficiency value then the NPF will be higher. Realized this, regulator should put more attention to maintain efficiency in good level. Since when the value is worsened, it will danger the problem loan ratio.

\section{Conclusion}

In this research we use CAMEL (Capital, Asset quality, Management, Earning and Liquidity) to test for behavior management hypothesis for sharia bank in Indonesia. We use four variables that related with CAMEL, which are Capital Adequacy Ratio (CAR), Non Performance Finance (NPF), Quick Ratio and Net Operation Margin (NOM). Capital is predicted by CAR, Asset quality is predicted by NPF, Quick ratio for liquidity and NOM for Earning.Those variables then regressed by panel least square based on Granger Causality test. The Granger Causality test itself is a test to see whether there's a relationship between two variables or not. To see the relationship, the dependent variable is regressed on lagged of the dependent variables and lagged of independent variables. How many lag that we choose is based on $\mathrm{R}^{2}$ and Akaike information criterion (Nachrowi, Nachrowi D.;Usman, 2006). Based on the regression, we found that bad management hypothesis is happen (Berger \& DeYoung, 1997). It shows that as efficiency become worsened, non performance finance will rise. This should be a warning for regulator so they able to maintain efficiency level. So this won't give any impact to non performance finance. 
The limitations from this research are it use ratio to predict the efficiency while others usually use efficiency frontier (Quadt \& Nguyen, 2016; Rossi et al., 2005). Other limitation is the years to use in this research. It should be longer than we proposed in this research.

\section{References}

[1] Achan, N. V. (2014). Analisis Kinerja Bank Syariah Murni dengan Bank Syraiah Campuran Pada Tahun 2011 dengan Menggunakan Metode CAMEL : Studi Kasus Pada Bank Syariah Diseluruh Dunia. Universitas Diponegoro.

[2] Bank Muamalat. (2015). Annual Report Bank Muamalat 2015.

[3] Berger, A. N., \& DeYoung, R. (1997). Problem Loans and Cost Efficiency in Commercial Banks. Journal of Banking \& Finance, 21(6), 849-870. http://doi.org/10.1016/S0378-4266(97)00003-4

[4] Berger, A. N., Hunter, W. C., \& Timme, S. G. (1993). The efficiency of financial institutions: A review and preview of research past, present and future. Journal of Banking and Finance, 17(2-3), 221-249. http://doi.org/10.1016/0378-4266(93)90030-H

[5] Demirgüc-Kunt, A. (1989). Deposit-Institution Failures: A Review of Empirical Literature. Federal Reserve Bank of Cleveland Economic Review, 25(4), 2-18.

[6] Enoch, Charles; Baldwin, Barbara; Frecaut, Olivier; Kovanen, A. (2001). Indonesia: Anatomy of a Banking Crisis Two Years of Living Dangerously 1997-1999. IMF Working Papers, 01/52(June), 555-582. Retrieved from http://www.countryanalyticwork.net/Caw/CawDocLib.nsf/5c5c47bfc0561e8c85256c5e000f5efd/98605C19C847FC4585256D7400 707470/\$file/wp01160.pdf

[7] Imansari, A. D. (2015). Analisa Perbandingan Kinerja Perbankan Syariah Berdasarkan Konsep Al-Maqashid Al-Syariah di Indonesia dan Malaysia. Diponegoro University.

[8] Nachrowi, Nachrowi D.;Usman, H. (2006). Pendekatan Populer dan Praktis Ekonometrika untuk Analisis Ekonomi dan Keuangan. (A. D. Prayoga, Ed.). Jakarta: Lembaga Penerbit Fakultas Ekonomi Universitas Indonesia.

[9] Podpiera, J., \& Weill, L. (2008). Bad Luck or Bad Management? Emerging Banking Market Experience. Journal of Financial Stability, 4(2), 135-148.

[10] Quadt, V., \& Nguyen, T. (2016). The Relation Between Efficiency, Non-Performing Loans And Capitalization in The Nordic Banking Sector. Lund University. Lund University.

[11] Reddy, K. S. (2011). Management Behaviour in Indian Commercial Banks. International Review of Accounting, Banking and Finance, 3(3), 70-92.

[12] Rossi, S. P. S., Schwaiger, M., \& Winkler, G. (2005). Managerial Behavior and Cost/Profit Efficiency in The Banking Sectors of Central and Eastern European Countries (No. 96). Working Paper 96.

[13] Shalendra D. Sharma. (2001). the Indonesian Financial Crisis : From Banking Crisis To Financial Sector Reforms, $1997-2000$. Indonesia, 71(71), 79-110.

[14] Whalen, G. (1991). A Proportional Hazards Model of Bank Failure: An Examination of Its Usefulness as an Early Warning Tool. Economic Review, Q1(1989), 21-31. 